OPEN ACCESS

Edited by:

Mohammad Bagher

Hassanpouraghdam,

University of Maragheh, Iran

Reviewed by:

Jessé Rodrigo Fink,

Instituto Federal do Paraná Câmpus

Palmas, Brazil

Bernardo Melo Montes Nogueira

Borges,

National Center for Research in

Energy and Materials, Brazil

*Correspondence:

Anelisa de Aquino Vidal Lacerda

Soares

avidal@sp.gov.br

Specialty section:

This article was submitted to

Plant-Soil Interactions,

a section of the journal

Frontiers in Soil Science

Received: 02 June 2021

Accepted: 26 July 2021

Published: 10 September 2021

Citation:

de Aquino Vidal Lacerda Soares A, de Mello Prado R, Caione G,

Rodrigues M, Pavinato PS and Naudi

Silva Campos C (2021) Phosphorus

Dynamics in Sugarcane Fertilized With

Filter Cake and Mineral Phosphate

Sources. Front. Soil Sci. 1:719651.

doi: 10.3389/fsoil.2021.719651

\section{Phosphorus Dynamics in Sugarcane Fertilized With Filter Cake and Mineral Phosphate Sources}

\author{
Anelisa de Aquino Vidal Lacerda Soares ${ }^{1 *}$, Renato de Mello Prado ${ }^{2}$, Gustavo Caione ${ }^{3}$, \\ Marcos Rodrigues ${ }^{4}$, Paulo Sérgio Pavinato ${ }^{4}$ and Cid Naudi Silva Campos ${ }^{5}$
}

\begin{abstract}
${ }^{1}$ Agência Paulista de Tecnologia dos Agronegócios, Bauru, Brazil, ${ }^{2}$ School of Agricultural and Veterinarian Sciences, São Paulo State University (UNESP), São Paulo, Brazil, ${ }^{3}$ Department of Agronomy, Mato Grosso State University (UEMT), Alta Floresta, Brazil, ${ }^{4}$ College of Agriculture "Luiz de Queiroz" - University of São Paulo, São Paulo, Brazil, ${ }^{5}$ Mato Grosso do Sul Federal University, Chapadão do Sul, Brazil
\end{abstract}

Organic residual material such as filter cake, combined with mineral phosphate fertilizers, may alter the soil phosphorus $(\mathrm{P})$ bioavailability for sugarcane as a consequence of the competing effect in adsorption sites. This study aimed to quantify the changes in both the inorganic and organic soil $P$ fractions as amended by phosphate fertilizer sources and filter cake and to link the $P$ fractions to sugarcane response. An experiment was conducted in an Oxisol, in a randomized block design with factorial arrangement of $4 \times 2$, and three replications. Three P fertilizer sources (triple superphosphate, Araxá rock phosphate, and Bayóvar ${ }^{\circledR}$ reactive phosphate) plus a control (no P) were evaluated under both the presence and absence of filter cake. At the end of the second crop cycle, the following were measured: the cane yield, the tissue P content, and soil P fractions. All fertilizer sources were efficient in supplying $P$ to sugarcane. Araxá rock phosphate generated a higher accumulation in moderately labile $\mathrm{P}$, whereas the soluble triple superphosphate resulted in higher labile P. The filter cake, as a source of nutrients and organic matter, has an important contribution to maintain more available $\mathrm{P}$ for sugarcane absorption, especially when associated with triple superphosphate. The amount of $\mathrm{P}$ absorbed by sugarcane was correlated with the soil labile $\mathrm{P}(r=0.58)$ and also with the inorganic $\mathrm{P}$ moderately labile $(r=0.42)$. Both fractions must be taken into account for a short- to medium-term availability of $\mathrm{P}$ for sugarcane in Oxisols.

Keywords: oxisol, triple superphosphate, rock phosphate, organic matter, soil P lability

\section{INTRODUCTION}

Sugarcane is one of the leading crops in Brazil thanks to its contribution to the economic, social, and environmental sectors, as well as being a viable alternative for renewable energy production $(1,2)$. This crop has great potential for stalk production, consequently requiring a high level of fertilizer input, since it is commonly cultivated in very weathered soils with low cation exchange capacity and high anion adsorption sites $(3,4)$. These tropical soils have naturally low total phosphorus (P) content and high $\mathrm{P}$ adsorption capacity, acting as a drain on inorganic $\mathrm{P}$ from the soil solution (5-7). Accordingly, phosphate fertilizer management assumes crucial importance at the planting stage of sugarcane, as it can optimize productivity and improve crop use efficiency, both at first harvest and in subsequent ratoons, and can increase the longevity of sugarcane plantations (8). This is 
justified by the high input of $\mathrm{P}$ fertilizers for sugarcane in Brazil, reaching up to $1,263 \mathrm{~kg} \mathrm{ha}^{-1}$ for the period of 1967-2016, with a corresponding $\mathrm{P}$ offtake of $420 \mathrm{~kg} \mathrm{ha}^{-1}$ in the same period (2).

There are many mineral $\mathrm{P}$ fertilizer sources available for sugarcane, with distinct agronomical properties. Those most commonly applied are the soluble phosphates such as single and triple superphosphate (SSP and TSP) and mono- and diammonium phosphate (MAP and DAP), accounting for more than $90 \%$ of the phosphates used in Brazil. In the short term, they exhibit high efficiency, but the remaining $\mathrm{P}$ in solution is strongly adsorbed to $\mathrm{Fe}$ and $\mathrm{Al}$ oxyhydroxides in the soil, resulting in strong competition between soil and plants for $\mathrm{P}$ from these sources (9). As an alternative, there are less soluble phosphates sources, such as natural rock phosphates. Although they have less immediate P availability to plants (10), these sources have a greater residual effect over the crop growth cycles. Albuquerque et al. (11) tested different sources and doses of $\mathrm{P}$ in sugarcane production, and they observed that Bayóvar reactive rock phosphate led to increases in stem diameter and dry matter at 120 days.

Faced with the high cost of mineral fertilizers, high $\mathrm{P}$ adsorption, and wide availability of organic material (filter cake) provided by the sugar-ethanol sector, there has been an upsurge in the use of this organic material together with mineral fertilizers in sugarcane. A valuable by-product of the ethanol and sugar manufacturing process, filter cake is generated during the process of clarifying the sugarcane juice and consists of crushed bagasse and decanted sludge (12), presenting a considerable percentage of organic matter and nutrients for reapplication in the soil, partially replacing mineral fertilizers (3). Furthermore, it is possible to increase the efficiency of phosphate fertilizers in its organomineral form, since filter cake can competitively reduce the attachment of $\mathrm{P}$ in specific adsorption sites in soil, thereby increasing $\mathrm{P}$ bioavailability $(13,14)$.

Chemical $\mathrm{P}$ fractionation is a good way to identify changes promoted by management, even by soil tillage, crop species, or fertilizers, in the soil $\mathrm{P}$ fractions $(15,16)$. Hedley et al. (17) proposed a procedure well used nowadays for a better comprehension of $\mathrm{P}$ dynamics. This technique uses chemical extractors applied in sequence to the same sample, to transfer soil $\mathrm{P}$, step by step, from the most available to the most stable inorganic $\mathrm{P}$ (Pi) and organic $\mathrm{P}(\mathrm{Po})$ fractions. With this procedure, we will be able to detect any modification promoted by filter cake or mineral fertilizers in soil $\mathrm{P}$ lability under sugarcane cultivation and consequently recommend management practices to improve $\mathrm{P}$ use efficiency in sugarcane fields.

There is evidence that after long periods of phosphate fertilization, distinct residual fractions are accumulated in the soil, with different degrees of binding energy (18-20). Thus, our hypothesis is that the presence of organic compounds associated with mineral fertilizer can increase the labile $\mathrm{P}$ fractions. However, this effect is dependent on phosphate sources, since filter cake can promote an increase in soil $\mathrm{pH}$, a situation whereby natural phosphates should maintain lower $\mathrm{P}$ in labile fractions $(21,22)$.
In this context, we aimed to quantify changes in both inorganic and organic soil $\mathrm{P}$ fractions when amended with distinct phosphate fertilizer sources associated with filter cake and to link the $\mathrm{P}$ fractions to $\mathrm{P}$ uptake and sugarcane yield.

\section{MATERIALS AND METHODS}

\section{Site Information}

A field experiment was conducted at Usina Catanduva SA, a company in Santa Adelia-SP, Brazil, located at latitude $21^{\circ} 20^{\prime} \mathrm{S}$, longitude $43^{\circ} 53^{\prime} \mathrm{W}$ and altitude of $600 \mathrm{~m}$. The soil is classified as Latossolo Vermelho (23), equivalent to Hapludox in Soil Taxonomy [Soil Survey (24)]. Original soil presented the following chemical properties at the 0-20-cm-depth layer (25): $\mathrm{pH}$ calcium chloride $\left(\mathrm{CaCl}_{2}\right)=6.0 ; \mathrm{P}($ resin $)=5.0 \mathrm{mg} \mathrm{kg}^{-1} ; \mathrm{K}^{+}$ $=1.4 \mathrm{mmol}_{\mathrm{c}} \mathrm{kg}^{-1} ; \mathrm{Ca}^{2+}=11 \mathrm{mmol}_{\mathrm{c}} \mathrm{kg}^{-1} ; \mathrm{Mg}^{2+}=6 \mathrm{mmol}_{\mathrm{c}}$ $\mathrm{kg}^{-1} ; \mathrm{H}^{+}+\mathrm{Al}^{3+}=11 \mathrm{mmol}_{\mathrm{c}} \mathrm{kg}^{-1}$; cation exchange capacity $=29 \mathrm{mmol}_{\mathrm{c}} \mathrm{kg}^{-1}$; base saturation $=63 \%$; and organic matter $=7.0 \mathrm{~g} \mathrm{~kg}^{-1}$. The remaining $\mathrm{P}$ was determined according to the methodology described by Alvarez et al. (26) obtaining the value of P-remaining $=19 \mathrm{mg} \mathrm{dm}^{-3}$. Contents of $\mathrm{Fe}_{2} \mathrm{O}_{3}, \mathrm{Al}_{2} \mathrm{O}_{3}$, and $\mathrm{SiO}_{2}$ were also evaluated with the respective values of $4.5,11.0$, and $13.2 \%$ (27). Textural composition of the soil was $180 \mathrm{~g} \mathrm{~kg}^{-1}$ of clay, $80 \mathrm{~g} \mathrm{~kg}^{-1}$ of silt, $390 \mathrm{~g} \mathrm{~kg}^{-1}$ of fine sand, and $350 \mathrm{~g} \mathrm{~kg}^{-1}$ of coarse sand (27).

\section{Experimental Design}

The trial followed a randomized complete block design with a factorial arrangement of $4 \times 2$ and three replications. Each plot was composed of five lines of sugarcane, $15 \mathrm{~m}$ long and $1.5 \mathrm{~m}$ between rows, with the three central lines considered useful for evaluation, except for the final $1.0 \mathrm{~m}$ at each side of the plot, which was discharged.

Three phosphate fertilizer sources were applied: TSP (44\% of total $\mathrm{P}_{2} \mathrm{O}_{5}$ and $41 \%$ soluble in $2 \%$ citric acid), Araxá rock phosphate (ARP) (22\% of total $\mathrm{P}_{2} \mathrm{O}_{5}$ and $4 \%$ soluble in $2 \%$ citric acid), and Bayóvar ${ }^{\circledR}$ reactive phosphate (BRP) (28\% of total $\mathrm{P}_{2} \mathrm{O}_{5}$ and $14 \%$ soluble in $2 \%$ citric acid) plus a control (without $\mathrm{P})$, in both the presence and absence of filter cake $\left(7.5 \mathrm{tha}^{-1}\right.$ dry mass). Phosphate fertilizer sources were applied at the sugarcane planting stage, at a dosage of $90 \mathrm{~kg} \mathrm{ha}^{-1} \mathrm{P}_{2} \mathrm{O}_{5}$ as soluble in citric acid, which represented $50 \%$ of the amount recommended by Raij et al. (25), in order to verify the possibility of reducing the mineral fertilizer when associated with filter cake.

Chemical characterization of filter cake was done following the methodology described by Bataglia et al. (28), presenting the following results based on dry mass $\left(60-65^{\circ} \mathrm{C}\right): N=14.0 \mathrm{~g} \mathrm{~kg}^{-1}$; $\mathrm{P}=9.2 \mathrm{~g} \mathrm{~kg}^{-1} ; \mathrm{K}=3.4 \mathrm{~g} \mathrm{~kg}^{-1} ; \mathrm{Ca}=25.3 \mathrm{~g} \mathrm{~kg}^{-1} ; \mathrm{Mg}=9.0 \mathrm{~g}$ $\mathrm{kg}^{-1} ; \mathrm{S}=3.3 \mathrm{~g} \mathrm{~kg}^{-1}$; $\operatorname{copper}(\mathrm{Cu})=43 \mathrm{mg} \mathrm{kg}^{-1}$; boron (B) $16 \mathrm{mg}$ $\mathrm{kg}^{-1}$; manganese $(\mathrm{Mn})=753 \mathrm{mg} \mathrm{kg}^{-1}$; iron $(\mathrm{Fe})=9.374 \mathrm{mg}$ $\mathrm{kg}^{-1}$; and zinc $(\mathrm{Zn})=70 \mathrm{mg} \mathrm{kg}^{-1}$.

At the planting furrow, about $0.25-0.30 \mathrm{~m}$ deep, filter cake and phosphate fertilizer were applied together. Then, sugarcane seedlings were distributed over the fertilizers and covered by a $0.10-0.15$-m layer of soil. After 40 days of planting, $50 \mathrm{~kg} \mathrm{ha}^{-1}$ of $\mathrm{N}$ as ammonium nitrate was applied (29). After the first harvest, in the second season, it was supplied with $120 \mathrm{~kg} \mathrm{ha}^{-1}$ of $\mathrm{N}$ and 
$120 \mathrm{~kg} \mathrm{ha}^{-1}$ of $\mathrm{K}_{2} \mathrm{O}$, with the sources ammonium nitrate and potassium chloride, respectively (29).

\section{Crop and Soil Evaluations}

Sugarcane yield was evaluated after 24 months, considering here only the yield of the first ratoon (second harvest) to evaluate the residual effect of phosphate sources and filter cake. From each of the three central rows, $3 \mathrm{~m}$ length was harvested manually. Stalks $\left(\mathrm{t} \mathrm{ha} \mathrm{h}^{-1}\right.$ ) and straw (dry weight) were weighed separately. Samples from each plant fraction were collected (dry leaves + top leaves + stalk) and dried in a forced air oven $\left(63-67^{\circ} \mathrm{C}\right)$ until reaching a constant dry mass mensuration. After drying, samples were ground in a Willey mill, and the $\mathrm{P}$ content was determined, according to Battaglia et al. (28). Based on these results, the $\mathrm{P}$ accumulation in the shoot was determined and, afterwards, correlated with the various $\mathrm{P}$ fractions in the soil.

Soil samples were taken at $0.0-0.30$-m-depth layer right after sugarcane harvest, coincident to the plant furrow (expected place to have greater fertilizer concentration). Composite samples were formed by mixing 20 subsamples, taken from the three central plant rows of each experimental unit. Soil samples were airdried and sieved through $2 \mathrm{~mm}$ prior to laboratory analysis. Soil organic matter (SOM) content was estimated according to Raij et al. (25).

Chemical P fractionation was performed following the methodology described by Hedley et al. (17), with some modifications, and the fractions were grouped according to their lability predicted by the extractants (30). Briefly, anion exchange resin-Presin-extracts labile inorganic $\mathrm{P}$ readily diffusing into solution using a resin membrane $\left(2.0 \mathrm{~cm}^{2}\right.$ in area); $0.5 \mathrm{~mol} \mathrm{~L}^{-1}$ $\mathrm{NaHCO}_{3}$ at $\mathrm{pH} 8.5$ extracts labile inorganic $\mathrm{P}\left(\mathrm{Pi} \mathrm{NaHCO}_{3}\right)$ and labile organic $\mathrm{P}\left(\mathrm{Po} \mathrm{NaHCO}_{3}\right)$ (31); $0.1 \mathrm{~mol} \mathrm{NaOH} \mathrm{L} \mathrm{L}^{-1}$ removes moderately labile inorganic $\mathrm{P}\left(\mathrm{Pi} \mathrm{NaOH} 0.1 \mathrm{~mol} \mathrm{~L}^{-1}\right)$ (17) and moderately labile organic P (Po NaOH $0.1 \mathrm{~mol} \mathrm{~L}^{-1}$ ) (32); $1.0 \mathrm{~mol}$ $\mathrm{HCl} \mathrm{L}^{-1}$ (PHCl) extracts moderately labile inorganic P linked to $\mathrm{Ca}$ (33); $0.5 \mathrm{~mol} \mathrm{NaOH} \mathrm{L}{ }^{-1}$ extracts more recalcitrant forms of inorganic $\mathrm{P}$ ( $\mathrm{Pi} 0.5 \mathrm{~mol} \mathrm{NaOH} \mathrm{L} \mathrm{L}^{-1}$ ) and non-labile forms of organic P (Po $0.5 \mathrm{~mol} \mathrm{NaOH} \mathrm{L}{ }^{-1}$ ) (34); and residual P (P Residual) obtained after the remaining soil was dried at $50^{\circ} \mathrm{C}$, milled, and digested with $\mathrm{H}_{2} \mathrm{SO}_{4}+\mathrm{H}_{2} \mathrm{O}_{2}$ in the presence of saturated $\mathrm{MgCl}_{2}$ (35). Total $\mathrm{P}(\mathrm{Pt})$ in the alkali extracts (Po $\mathrm{NaHCO}_{3}$, Po NaOH $0.1 \mathrm{~mol} \mathrm{~L}^{-1}$, and $\mathrm{Po} \mathrm{NaOH} 0.5 \mathrm{~mol} \mathrm{~L}^{-1}$ ) was determined by digestion with sulfuric acid $\left(\mathrm{H}_{2} \mathrm{SO}_{4}\right)$ and ammonium persulfate (36). Inorganic $\mathrm{P}$ in alkali extracts was measured colorimetrically by Dick and Tabatabai (37). Inorganic $\mathrm{P}$ in acid extracts (Presin and $\mathrm{PHCl}$; and digestion of $\mathrm{Pt} \mathrm{NaHCO}_{3}$, $\mathrm{Pt} \mathrm{NaOH} 0.1 \mathrm{~mol} \mathrm{~L}^{-1}$, and $\mathrm{Pt} \mathrm{NaOH} 0.5 \mathrm{~mol} \mathrm{~L}^{-1}$ ) was measured colorimetrically by Murphy and Riley (38). Organic P in alkali extracts was obtained by difference between $\mathrm{Pt}$ and $\mathrm{Pi}$.

Agronomic efficiency of sugarcane production was calculated considering the sugarcane yield under phosphate sources, being determined by Borges et al. (39):

Agronomic efficiency $=$ [stalk yield with $\mathrm{P}$ - stalk yield without $\mathrm{P} /$ dose of $\mathrm{P}$ applied] $\times 100$.

\section{Statistical Analysis}

Data about $\mathrm{P}$ fractions and sugarcane yield were subjected to analysis of variance (ANOVA), comparing the factors $\mathrm{P}$ fertilizer source and filter cake separately and their interaction. For significant interaction, filter cake effect on each $\mathrm{P}$ fertilizer source was compared by Tukey's test $(p<0.05)$. In cases of nonsignificant interaction, the means of each factor were compared by Tukey's test ( $p<0.05)$, using the SAS program 9.1. Furthermore, a simple linear correlation between data tests and correlation analyses between $\mathrm{P}$ fractions and accumulated $\mathrm{P}$ in tissue was plotted using the AgroEstat statistical program (40).

\section{RESULTS AND DISCUSSION}

\section{Soil P Fractions}

Most of the $\mathrm{P}$ fractions were not affected by interaction between phosphate sources and filter cake but were affected by each factor in an isolated way (Table 1), except for the non-labile fraction $\mathrm{Pi} \mathrm{NaOH} 0.5 \mathrm{~mol} \mathrm{~L}^{-1}$ (Figure 1). Although the dosage of soluble $\mathrm{P}$ was the same for all sources, TSP was more effective in raising the soil available $\mathrm{P}$ compared with $\mathrm{BRP}$, ARP, and control, as observed for the levels extracted by $\mathrm{P}$ resin (Table 1). This means that $\mathrm{P}$ solubility from BRP and ARP is very low in the short to medium term, especially in soils with higher $\mathrm{Ca}$ levels and high $\mathrm{pH}$, as observed in the initial soil characterization of the present study. As soil samples were collected after the second year of sugarcane cultivation/fertilizer application, it implies that BRP and ARP were not effective in keeping the adequate levels of soil available P. Similar results were reported by Oliveira et al. (41) in a study evaluating soil $\mathrm{P}$ fractions under pasture subjected to phosphate amendment.

Filter cake was able to keep higher levels of $\mathrm{P}$ resin after 24 months (Table 1). Around 50\% of the phosphate present in filter cake is readily available, while the remaining part is slowly mineralized in the soil over the years (42). Furthermore, higher total organic carbon content after applying filter cake promotes competition between available $\mathrm{P}$ and low-molecularweight organic acids for the same adsorption sites (43), keeping more $\mathrm{P}$ in labile fractions in the soil. Accordingly, Bittencourt et al. (44) recommended an organic carrier such as filter cake to avoid $\mathrm{P}$ fixation and thereby increase the efficiency of phosphate fertilizers in sugarcane, with a possible reduction of phosphate doses over time.

A similar behavior was observed for Pi and Po extracted by $\mathrm{NaHCO}_{3}$ as compared with P resin (Table 1), with TSP being the best source for keeping higher levels of all labile $\mathrm{P}$ fractions in the soil. Due to the importance for plants of both $\mathrm{NaHCO}_{3}$ fractions (Pi and Po), Gonçalves and Meurer (45) suggested that they could be included as $\mathrm{P}$ available indices in fertilizer recommendation bulletins, especially in low availability of soils and low fertilizer inputs. Under filter cake application, a significant increase in both $\mathrm{Pi}$ and $\mathrm{Po} \mathrm{NaHCO}_{3}$ levels was observed when compared with the absence of filter cake. Moreover, most of the $\mathrm{P}$ extracted by $\mathrm{NaHCO}_{3}$ is in an inorganic form, which makes it ready for plant absorption in a short time [(46-50)]. 


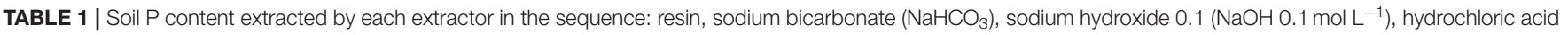
$\left(\mathrm{HCl} 1 \mathrm{~mol} \mathrm{~L}^{-1}\right)$, sodium hydroxide $0.5\left(\mathrm{NaOH} 0.5 \mathrm{~mol} \mathrm{~L}^{-1}\right)$, residual and total in soil samples cultivated with sugarcane under phosphate sources (P) and filter cake (FC) application.

\begin{tabular}{|c|c|c|c|c|c|c|c|c|c|c|}
\hline \multirow{4}{*}{ P Source } & \multicolumn{3}{|c|}{ Labile } & \multicolumn{3}{|c|}{ Moderately labile } & \multicolumn{3}{|c|}{ Non-labile } & \multirow{4}{*}{ Total P } \\
\hline & \multirow[t]{2}{*}{$\mathrm{P}$ resin } & \multicolumn{2}{|c|}{$\mathrm{NaHCO}_{3}$} & \multicolumn{2}{|c|}{$\mathrm{NaOH}\left(0.1 \mathrm{~mol} \mathrm{~L}^{-1}\right)$} & \multirow[t]{2}{*}{ P (HCl) } & \multicolumn{2}{|c|}{$\mathrm{NaOH}\left(0.5 \mathrm{~mol} \mathrm{~L}^{-1}\right)$} & \multirow[t]{3}{*}{ Residual P } & \\
\hline & & $\mathbf{P i}$ & Po & $\mathbf{P i}$ & Po & & $\mathbf{P i}$ & Po & & \\
\hline & \multicolumn{8}{|c|}{$\mathrm{mg} \mathrm{kg}^{-1}$} & & \\
\hline Control & $12.5^{\mathrm{b}}$ & 21.4 & 4.3 & $18.8^{b}$ & $25.9^{b, c}$ & $6.7^{\mathrm{c}}$ & $22.1^{\mathrm{b}}$ & 23.9 & 133.7 & $269.6^{b}$ \\
\hline $\mathrm{ARP}^{\S}$ & $12.1^{\mathrm{b}}$ & 18.5 & 4.5 & $18.7^{\mathrm{b}}$ & $35.9^{a}$ & $62.7^{a}$ & $43.3^{a}$ & 24.9 & 137.5 & $358.0^{a}$ \\
\hline $\mathrm{BRP}$ & $15.6^{b}$ & 21.7 & 4.3 & $19.0^{b}$ & $31.5^{a, b}$ & $32.4^{b}$ & $27.8^{b}$ & 19.5 & 139.9 & $311.9^{a, b}$ \\
\hline TSP & $22.5^{\mathrm{a}}$ & 31.5 & 7.4 & $29.8^{a}$ & $22.0^{\mathrm{C}}$ & $12.1^{\mathrm{c}}$ & $20.4^{b}$ & 15.9 & 125.7 & $287.7^{b}$ \\
\hline DMS & 6.49 & 13.66 & 5.00 & 7.58 & 8.76 & 17.42 & 9.53 & 18.33 & 23.32 & 47.22 \\
\hline \multicolumn{11}{|c|}{ Filter cake (FC) } \\
\hline Without & $8.2^{b}$ & $15.9^{\mathrm{b}}$ & $2.3^{b}$ & $14.5^{\mathrm{b}}$ & 29.4 & 29.3 & 27.8 & $12.7^{b}$ & 131.9 & $272.1^{b}$ \\
\hline With & $23.1^{a}$ & $30.6^{a}$ & $8.0^{a}$ & $28.6^{a}$ & 28.2 & 27.7 & 29.2 & $29.5^{a}$ & 136.5 & $341.5^{\mathrm{a}}$ \\
\hline LSD & 6.49 & 7.12 & 2.60 & 3.95 & 4.57 & 9.08 & 4.97 & 9.55 & 12.15 & 24.61 \\
\hline \multicolumn{11}{|l|}{ F-test } \\
\hline$P$ & $9.38^{\star \star}$ & $2.90^{\mathrm{ns}}$ & $1.56^{\mathrm{ns}}$ & $8.74^{\star \star}$ & $8.13^{\star \star}$ & $35.80^{\star \star}$ & $19.93^{\star \star}$ & $0.86^{n s}$ & $1.20^{\mathrm{ns}}$ & $11.10^{\star \star}$ \\
\hline FC & $89.01^{\star *}$ & $19.43^{\star \star}$ & $22.29^{\star *}$ & $58.28^{\star \star}$ & $0.29^{n s}$ & $0.14^{\mathrm{ns}}$ & $0.35^{\mathrm{ns}}$ & $14.08^{\star \star}$ & $0.66^{\mathrm{ns}}$ & $36.51^{\star \star}$ \\
\hline$P \times F C$ & $0.76^{n s}$ & $0.47^{n s}$ & $0.15^{\mathrm{ns}}$ & $0.60^{\text {ns }}$ & $1.35^{\mathrm{ns}}$ & $0.25^{\text {ns }}$ & $4.73^{\star}$ & $1.25^{\mathrm{ns}}$ & $0.89^{n s}$ & $1.45^{\mathrm{ns}}$ \\
\hline CV (\%) & 24.6 & 34.9 & 57.89 & 20.3 & 18.1 & 36.5 & 19.6 & 51.1 & 10.5 & 9.7 \\
\hline
\end{tabular}

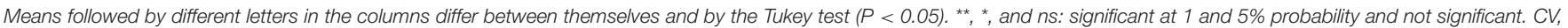
coefficient of variation. ${ }^{\S}$ ARP, Araxá Rock Phosphate; BRP, Bayóvar reactive phosphate. TSP, triple superphosphate. Pi, inorganic phosphorus. Po, organic phosphorus.

The $\mathrm{P}$ fraction extracted by $\mathrm{NaOH} 0.1 \mathrm{~mol} \mathrm{~L}^{-1}$ is an indicator of the $\mathrm{P}$ adsorbed to $\mathrm{Fe}$ and $\mathrm{Al}$ oxides in the soil and composes the moderately labile $\mathrm{P}$ pool $(17,51)$. According to Dias (52), all the soluble $\mathrm{P}$ added via TSP or via apatite dissolution (natural phosphate) might be adsorbed to Fe and $\mathrm{Al}$ oxides. In this way, it is possible to follow the dissolution of calcium phosphates by extracting with $\mathrm{NaOH}$. TSP had a higher amount of inorganic $\mathrm{P}\left(\mathrm{Pi} \mathrm{NaOH} 0.1 \mathrm{~mol} \mathrm{~L}^{-1}\right)$, and natural phosphates (ARP and BRP) had a higher amount of organic $\mathrm{P}$ (Po NaOH $0.1 \mathrm{~mol} \mathrm{~L}^{-1}$ ) (Table 1) in this extractor compared with the others. Carneiro et al. (53) reported similar results while studying soil $\mathrm{P}$ responses to phosphate fertilization in an Oxisol under different land uses. The increment in this organic $\mathrm{P}$ fraction reduces soil $\mathrm{P}$ reactivity in clay structure, especially under low $\mathrm{P}$ or in predominantly low clay activity $(54,55)$, which can ensure that more $\mathrm{P}$ would be absorbed by crops.

It is worth mentioning that all the phosphate fertilizers were applied on planting furrow, thereby restricting soil contact. As there were no differences in $\mathrm{Pi} \mathrm{NaOH} 0.1 \mathrm{~mol} \mathrm{~L}^{-1}$ fraction between ARP, BRP, and the control, there was low dissolution of these rock phosphates throughout the two crop cultivation seasons, even under acidic soil conditions and under low $\mathrm{P}$ and $\mathrm{Ca}$ original levels. Oliveira et al. (41), evaluating soil P fractions under natural pasture under phosphate sources, also reported low reactivity of Gafsa rock phosphate. Moreover, the amount of $\mathrm{P}$ in moderately labile fraction was higher under TSP, reaching mean values of $51.8 \mathrm{mg} \mathrm{kg}^{-1}$ of $\mathrm{Pi}+$ Po than $44.7 \mathrm{mg}$ $\mathrm{kg}^{-1}$ of the same fractions for non-fertilized soil (Table 1).
Moreover, $18 \%$ of the total $\mathrm{P}$ in soil under TSP application was found in these moderately labile fractions. There was no effect of filter cake on the Po $\mathrm{NaOH} 0.1 \mathrm{~mol} \mathrm{~L}^{-1}$ fraction, differing from labile Po fraction $\left(\mathrm{Po} \mathrm{NaHCO}_{3}\right)$. Similarly, Caione et al. (18) reported that filter cake was not able to change Po $\mathrm{NaOH} 0.1 \mathrm{~mol} \mathrm{~L}^{-1}$. Gatiboni et al. (56), working with successive applications of liquid swine manure in a natural grazing situation, also observed low agronomic importance of that organic material in terms of increasing the $\mathrm{Po} \mathrm{NaOH} 0.1 \mathrm{~mol}$ $\mathrm{L}^{-1}$ fraction.

The P levels estimated by hydrochloric acid extractor ( $\mathrm{PHCl})$ indicate that ARP returned the highest value in this fraction, followed by BRP. TSP was much lower than rock phosphates, similar to the control (Table 1). Gatiboni (57) added that the $\mathrm{HCl}$ extractor can detect the $\mathrm{P}$ associated with phosphate fertilizer without previous solubilization, for example, rock phosphates, thus justifying the higher results obtained here. Otherwise, filter cake addition did not affect $\mathrm{PHCl}$ fraction. Similarly, Soltangheisi et al. (58) observed that $\mathrm{PHCl}$ was not influenced when evaluating whether the long-term sugarcane straw removal should change soil $P$ dynamics.

Among the $\mathrm{P}$ fractions determined by the $\mathrm{NaOH} 0.5 \mathrm{~mol}$ $\mathrm{L}^{-1}$ extractor, inorganic $\mathrm{P}$ was greater under ARP application than other sources (Table 1), which may be justified by the amount of $\mathrm{P}$ present in non-available form in ARP, as tricalcium phosphate. Supposedly, the drop in $\mathrm{pH}$ under previous $\mathrm{HCl}$ extraction promoted changes in rock phosphate structure that makes subsequent extraction by $\mathrm{NaOH}$ more effective. This explains the lowest $\mathrm{Pi} \mathrm{NaOH} 0.5 \mathrm{~mol} \mathrm{~L}^{-1}$ under TSP, because 


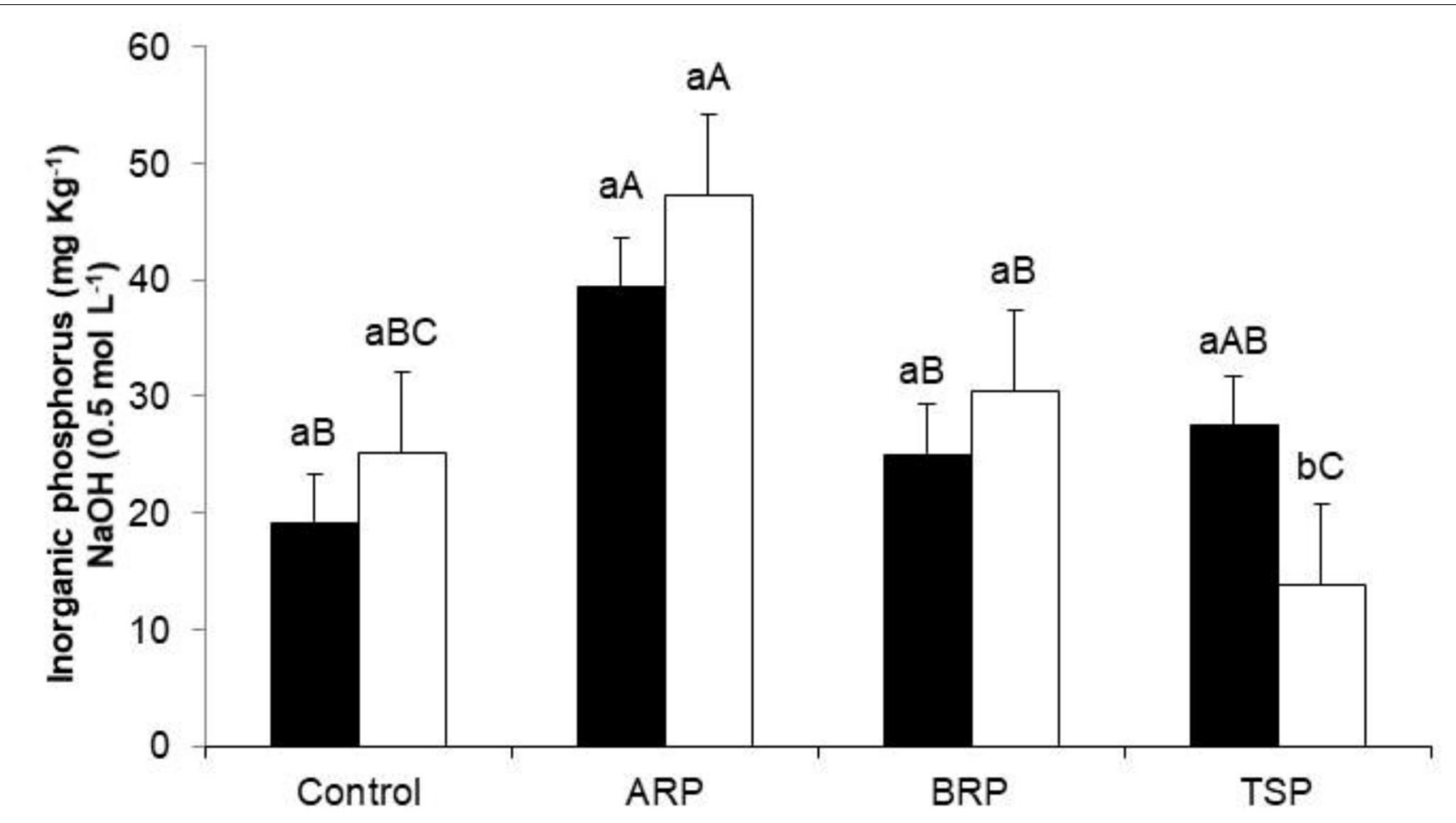

-Without filter cake

$\square$ With filter cake

FIGURE 1 | Interaction of phosphate sources (ARP, Araxá Rock Phosphate; BRP, Bayóvar reactive phosphate; TSP, triple superphosphate) and filter cake application in sugarcane on inorganic $\mathrm{P}$ extracted by $\mathrm{NaOH} 0.5 \mathrm{~mol} \mathrm{~L}^{-1}$. Means followed by the same letter in each source, comparing with and without filter cake, do not differ significantly at the level of $p<0.05$ by Tukey's test.

this source has kept $\mathrm{P}$ in soluble forms, determined through previous extractions. The more recalcitrant organic $\mathrm{P}$ fraction (Po $\mathrm{NaOH} 0.5 \mathrm{~mol} \mathrm{~L}^{-1}$ ) was not influenced by phosphate sources. Organic P fractions are not normally changed by phosphate fertilization in clay soils (59). This is supported by our current results, except in the case of the Po $\mathrm{NaOH}$ $0.1 \mathrm{~mol} \mathrm{~L}^{-1}$ fraction. The presence of filter cake was the only factor that influenced $\mathrm{Po} \mathrm{NaOH} 0.5 \mathrm{~mol} \mathrm{~L}^{-1}$. The $\mathrm{NaOH}$ $0.5 \mathrm{~mol} \mathrm{~L}^{-1}$ extractor also presented significant interaction between phosphate sources and filter cake in $\mathrm{Pi} \mathrm{NaOH} 0.5 \mathrm{~mol}$ $\mathrm{L}^{-1}$ fraction, as previously mentioned, but only under TSP application; other sources were similar with or without filter cake (Table 1, Figure 1).

Residual $\mathrm{P}$ fraction indicates no differences between treatments, regardless of the phosphate source and/or filter cake use (Table 1). This means that this non-labile fraction, represented by both organic and inorganic $\mathrm{P}$ forms of high recalcitrance, is barely accessed by selective chemical extractors, presenting a lower influence on the soil $\mathrm{P}$ adsorption process when phosphate fertilizers are added [30, Gatiboni et al. (60)]. However, the largest P contents, $38-49 \%$ of the total, were found in this fraction. Similarly, Santos et al. (61), when evaluating $\mathrm{P}$ fractions in a Paleudult clayey soil under corn cultivation with distinct fertilizer managements and sources, detected 55\% of total $\mathrm{P}$ in this residual fraction. Cross and Schlesinger (30) also reported that the added P tends to accumulate preferentially in labile fractions, with little or no effect on the residual fraction. Otherwise, soils with higher phosphate adsorption capacity may have a high proportion of $\mathrm{P}$ strongly adsorbed, being extracted only by strong acidic digestion. Rodrigues et al. (62) pointed out that in Brazilian Cerrado soils, the tendency is to accumulate $\mathrm{P}$ in moderately to non-labile pools when receiving regular phosphate fertilizer additions.

There was an increment in SOM content after 24 months under the application of filter cake (Table 2). Santos et al. (63) pointed out that the filter cake residue, composed of a mixture of bagasse and decanting sludge, has high levels of organic matter, $\mathrm{P}$, and $\mathrm{Ca}$. The increase in organic matter content has interfered in such a way that more $\mathrm{P}$ remained in available forms (labile) in the soil, as had been observed for the contents of $\mathrm{P}$ resin and $\mathrm{P} \mathrm{NaHCO}_{3}$ (Table 1). Moreover, the moderately labile and non-labile $\mathrm{P}$ fractions were also influenced by filter cake addition, with higher content of $\mathrm{Pi}$ $\mathrm{NaOH} 0.1 \mathrm{~mol} \mathrm{~L}^{-1}$ and Po $\mathrm{NaOH} 0.5 \mathrm{~mol} \mathrm{~L}^{-1}$. Accordingly, Korndörfer and Anderson (64) mentioned that filter cake promotes significant changes in soil chemical attributes, such as increasing $\mathrm{P}$ availability, which was also observed by Borges 
et al. (39) on organomineral phosphate fertilizer derived from sugarcane straw, highlighting the importance of filter cake as a source of organic matter and its effects on soil nutrient availability

TABLE 2 | Soil organic matter (SOM), tissue P accumulation (stalk + straw), and stalk yield of sugarcane (first ratoon) fertilized with phosphate sources and filter cake.

\begin{tabular}{|c|c|c|c|}
\hline P source & $\begin{array}{l}\text { SOM content } \\
\mathrm{kg} \mathrm{m}^{-3}\end{array}$ & 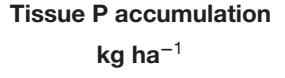 & $\begin{array}{l}\text { Stalk cane yield } \\
\qquad \mathrm{tha}^{-1}\end{array}$ \\
\hline Control & 11 & $19.5^{\mathrm{b}}$ & $82.5^{\mathrm{C}}$ \\
\hline ARP & 10 & $23.3^{\mathrm{b}}$ & $106.3^{b, c}$ \\
\hline BRP & 10 & $23.5^{\mathrm{b}}$ & $126.7^{a, b}$ \\
\hline TSP & 11 & $32.9 a$ & $131.2^{\mathrm{a}}$ \\
\hline \multicolumn{4}{|c|}{ Filter cake (FC) } \\
\hline Without & $9^{b}$ & $21.3^{\mathrm{b}}$ & 110.6 \\
\hline With & $12^{\mathrm{a}}$ & $28.4^{\mathrm{a}}$ & 112.8 \\
\hline \multicolumn{4}{|l|}{$F$-test } \\
\hline$P$ & $1.57^{\mathrm{ns}}$ & $8.28^{\star \star}$ & $13.56^{\star \star}$ \\
\hline $\mathrm{FC}$ & $34.71^{\star \star}$ & $12.83^{\star \star}$ & $0.14^{\mathrm{ns}}$ \\
\hline$P \times F C$ & $2.71^{\mathrm{ns}}$ & $4.82^{\star}$ & $0.73^{\mathrm{ns}}$ \\
\hline CV (\%) & 8.53 & 19.67 & 13.24 \\
\hline
\end{tabular}

Means followed by different letters in the columns differ between themselves according to the Tukey test $(P<0.05)$. ${ }^{* *},{ }^{*}$, and ns: significant at 1 and $5 \%$ probability and not significant. CV, coefficient of variation; ARP, Araxá Rock Phosphate; BRP, Bayóvar reactive phosphate; TSP, triple superphosphate. and sugarcane yield. Moreover, organic acids released from the mineralization of organic residues such as filter cake can block $\mathrm{P}$ sorption sites in soil and consequently release $\mathrm{P}$ to the soil solution (65). Additionally, enhanced SOM activity of P solubilizing microorganisms leads to increased $\mathrm{P}$ availability for plant uptake (66).

\section{Soil P Fractions and Crop P Uptake}

The accumulation of $\mathrm{P}$ in sugarcane tissue (stalk + straw) was more expressive under both TSP and filter cake (Table 2), with significant interaction by Tukey's test $(p<0.05)$ between them. Consequently, cane yield was influenced by $\mathrm{P}$ accumulation, being higher under TSP than under other sources. Cane yield under BRP did not differ according to Tukey's test $(p<0.05)$ from TSP and ARP, but the latter was far lower than TSP. The lowest yield was found in the control, differing from all $\mathrm{P}$ sources. Filter cake did not affect cane yield, although an extra amount of $\mathrm{P}$ and $\mathrm{N}$ was applied with filter cake. Similarly, Vasconcelos et al. (67), evaluating the management of $\mathrm{P}$ fertilizers and filter cake on the nutritional status and sugarcane yield in an Oxisol, highlighted the great effect of TSP on tissue $\mathrm{P}$ accumulation. They also verified higher $\mathrm{P}$ accumulation under filter cake than without it, similar to the present results (Table 2). The interaction triggering the accumulation of $\mathrm{P}$ indicates that filter cake effect was more pronounced when associated with TSP (Figure 2). Possibly, organic compounds from filter cake released into the soil were responsible in keeping more $\mathrm{P}$ in labile fractions under

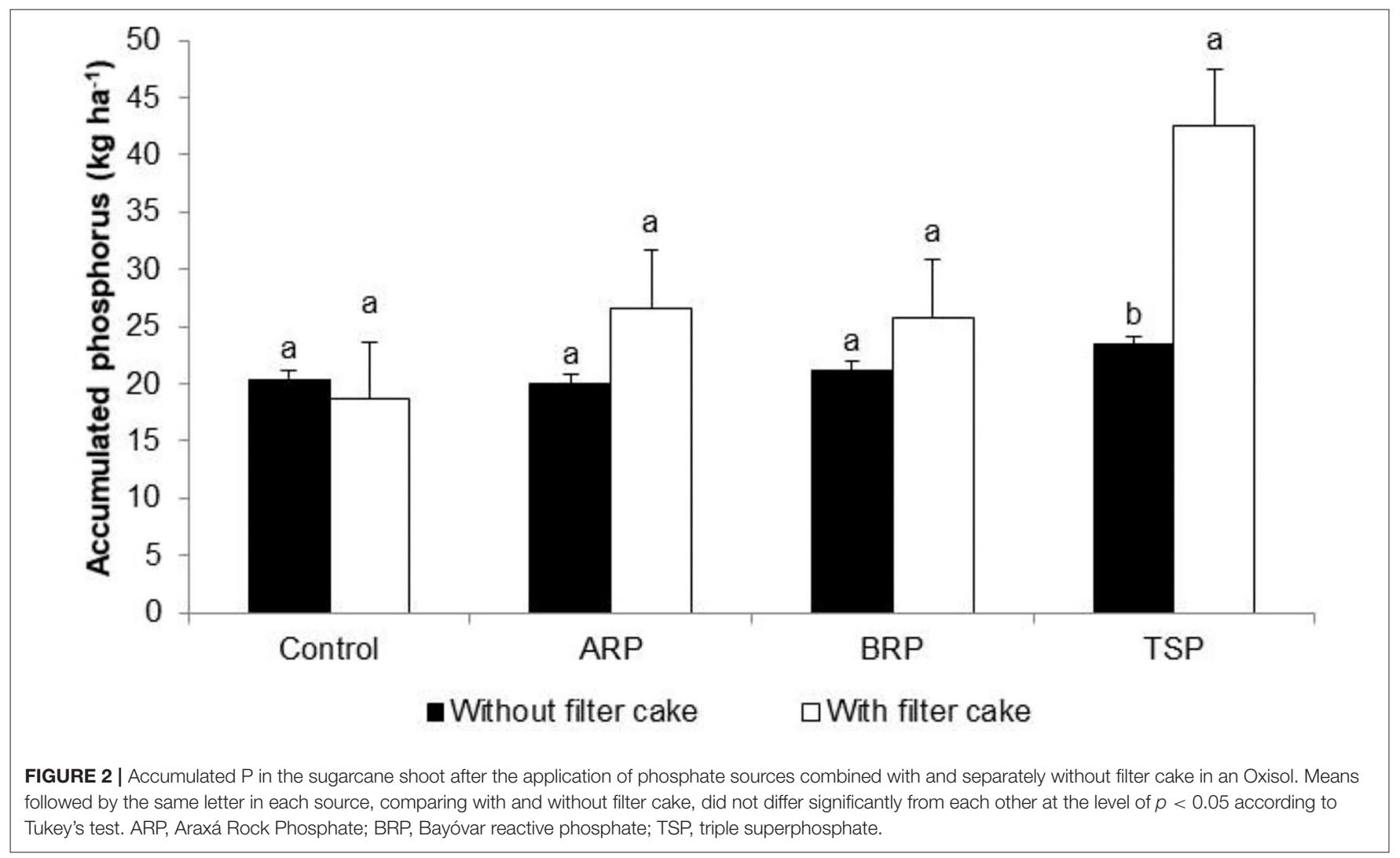




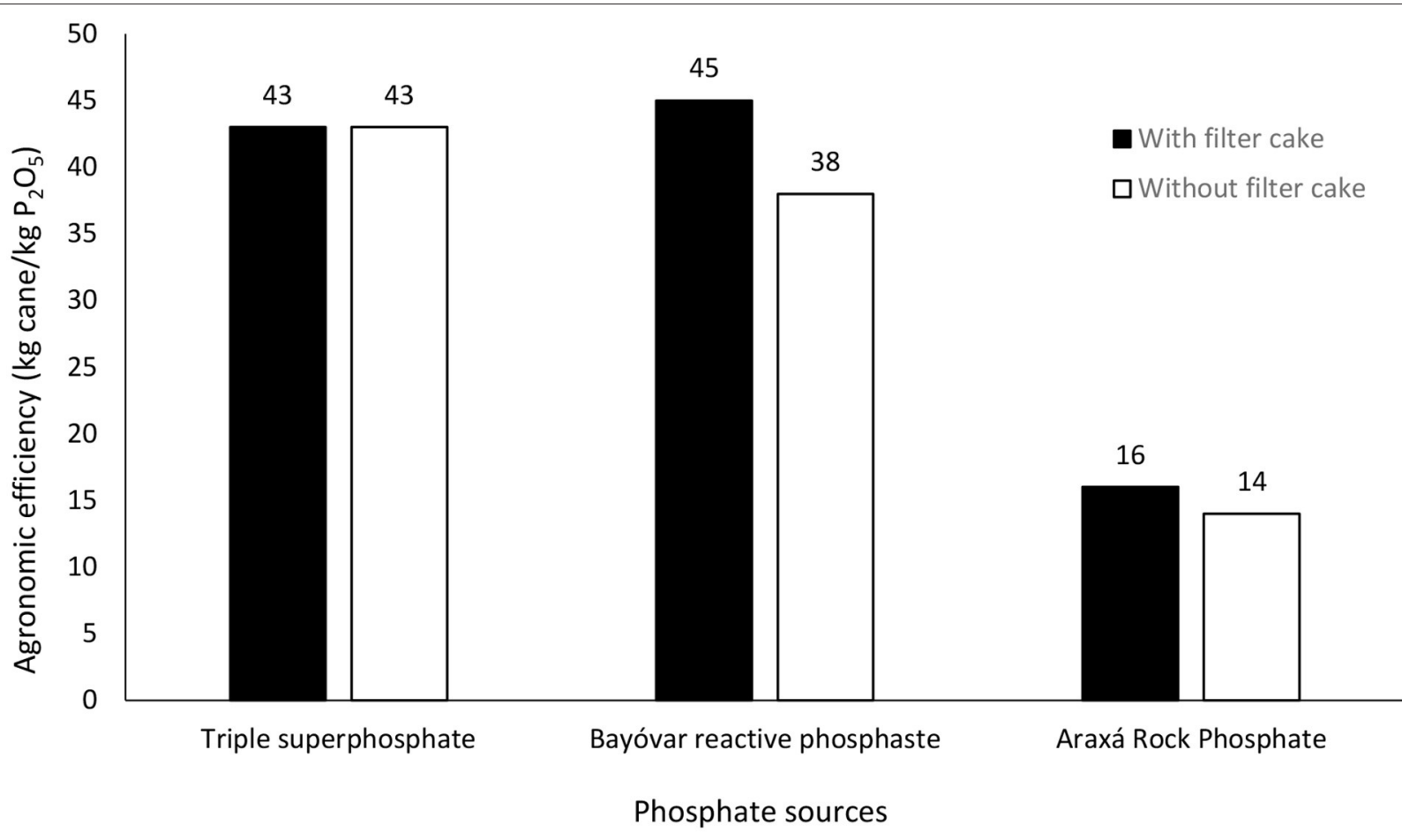

FIGURE 3 | Agronomic efficiency of distinct phosphate fertilizers combined with filter cake in an Oxisol in Southern Brazil.

TSP, thereby facilitating absorption by plants, which was not observed under rock phosphate sources.

In addition, it was possible to observe that the increase in agronomic efficiency of sugarcane after the addition of filter cake was more pronounced when associated with the natural phosphates BRP and ARP (Figure 3). It demonstrates that there is an interaction between OM and phosphate fertilizers, which can be explained by participation of organic acids in avoiding $\mathrm{P}$ adsorption, as well as in the solubilization of natural phosphates due to the supply of $\mathrm{H}^{+}$and $\mathrm{Ca}^{+2}$ complexation by organic acids, thus favoring the dissolution reactions $(68,69)$. Under TSP, there was no difference with and without filter cake, although the agronomic efficiency was the highest. Similar observations were found by Matias (70) when evaluating the agronomic efficiency of phosphate fertilizers in soils with distinct adsorption capacity and distinct $\mathrm{OM}$ content.

A pooled analysis of this study revealed that the effects of differential solubility fertilizer sources in the soil $\mathrm{P}$ fractions interfered, for the most part, in the moderately labile fraction $\left(\mathrm{P} \mathrm{NaOH} 0.1 \mathrm{~mol} \mathrm{~L}^{-1}\right.$ and $\mathrm{P} \mathrm{HCl}$ ) and to a lesser extent in the fractions that comprise the inorganic labile $\mathrm{P}\left(\mathrm{Pi} \mathrm{NaHCO}_{3}\right.$ and $\mathrm{P}$ resin). The gradual and restricted release of $\mathrm{P}$ from less soluble sources (BRP and ARP) resulted in a residual effect different from that produced by the most soluble sources. In the case of TSP, the fast $\mathrm{P}$ solubilization made the demand of sugarcane less dependent on soil reserves, which led to the maintenance of P stocks of both labile and moderately labile (organic and inorganic) fractions over the first 2 years of cultivation. As for the other sources, slower P release meant that there was a greater mobilization of organic and inorganic soil reserves to meet the demand for crop cultivation, providing less stock from the most labile fractions of $\mathrm{Pi}$ and Po. The presence of filter cake contributed to the soil $\mathrm{P}$ remaining as much in the more labile $\left(\mathrm{Pi} \mathrm{NaHCO}_{3}\right.$ and $\mathrm{P}$ resin) as in the less labile fractions.

\section{CONCLUSIONS}

1. The filter cake, as a source of nutrients and organic matter, has an important contribution to maintain more available $\mathrm{P}$ for sugarcane absorption, especially when associating with TSP.

2. Phosphate fertilizer sources were efficient in supplying $P$ to sugarcane, especially TSP, followed by BRP. ARP promoted the highest accumulation of $\mathrm{P}$ in the moderately labile fractions in the soil, while the other sources left more $\mathrm{P}$ in labile fractions.

3. The $\mathrm{P}$ absorbed by sugarcane was highly correlated with the labile P fractions ( $\mathrm{P}$ resin, $\mathrm{Pi} \mathrm{NaHCO}_{3}$, and $\mathrm{Po} \mathrm{NaHCO}_{3}$ ) and also with the inorganic moderately labile $\mathrm{P}$ fraction $(\mathrm{Pi}$ $\mathrm{NaOH} 0.1 \mathrm{~mol} \mathrm{~L}^{-1}$ ). Those fractions should be considered when estimating $P$ availability in sugarcane.

\section{DATA AVAILABILITY STATEMENT}

The original contributions presented in the study are included in the article/supplementary materials, further inquiries can be directed to the corresponding author/s. 


\section{AUTHOR CONTRIBUTIONS}

All authors listed have made a substantial, direct and intellectual contribution to the work, and approved it for publication.

\section{REFERENCES}

1. CONAB - Companhia Nacional de Abastecimento. Acompanhamento De Safra Brasileira: Cana-de-açúcar, Quarto Levantamento (2019). Brasilia: CONAB (2019).

2. Soltangheisi A, Withers PJ, Pavinato PS, Cherubin MR, Rossetto R, Do Carmo JB, et al. Improving phosphorus sustainability of sugarcane production in Brazil. Gcb Bioenergy. (2019) 11:1444-55. doi: 10.1111/gcbb.12650

3. Santos DH, Tiritan CS, Foloni JSS. Residual effect of phosphorus fertilization and filter cake on budding ratoon sugarcane. Agrarian Magazine. (2012) 5:1-6.

4. Withers PJ, Rodrigues M, Soltangheisi A, De Carvalho TS, Guilherme LR, Benites VDM, et al. Transitions to sustainable management of phosphorus in Brazilian agriculture. Sci Rep. (2018) 8:2537. doi: 10.1038/s41598-018-20887-z

5. Novais RF, Smyth TJ. Phosphorus in Soils and Plants in Tropical Conditions. Viçosa: Federal University of Viçosa, Brazil (1999).

6. Roy ED, Richards PD, Martinelli LA, Della Coletta L, Lins SRM, Vazquez FF, et al. The phosphorus cost of agricultural intensification in the tropics. Nat Plants. (2016) 2:16043. doi: 10.1038/nplants.2016.43

7. Gumiere T, Rousseau AN, da Costa DP, Cassetari A, Cotta SR, Andreote FD, et al. Phosphorus source driving the soil microbial interactions and improving sugarcane development. Sci Rep. (2019) 9:4400. doi: 10.1038/s41598-019-40910-1

8. Moda LR, Prado R, de M, Caione G, Campos CNS, Silva EC, et al. Effect of sources and rates of phosphorus associated with filter cake on sugarcane nutrition and yield. Austral J Crop Sci. (2015) 9:477-85.

9. Novais RF, Smyth TJ, Nunes FN. Phosphorous. Soil Fertility. Viçosa: Sociedade Brasileira de Ciência do Solo (2007). p. 471-537.

10. Horowitz N, Meurer EJ. Agronomic Efficiency of Rock Phosphate. Piracicaba: Potafos (2004). p. 665-88.

11. Albuquerque AW, Sá LA, Rodrigues WAR, Moura AB, Oliveira Filho MS. Growth and yield of sugarcane as a function of phosphorus doses and forms of application. Rev Bras Eng Agrícola e Ambient. (2016) 20:2935. doi: 10.1590/1807-1929/agriambi.v20n1p29-35

12. Prado R, de M, Caione G, Campos CNS. Filter cake, and vinasse as fertilizers contributing to conservation agriculture. Appl Environ Soil Sci. (2013) 2013:581984. doi: 10.1155/2013/581984

13. Hunt JF, Ohno T, He Z, Honeycutt CW, Dail DB. Inhibition of phosphorus sorption to goethite, gibbsite and kaolin by fresh and decomposed organic matter. Fertil Soils Biol. (2007) 44:277-88. doi: 10.1007/s00374-007-02 02-1

14. Yang X, Chen X, Yang X. Effect of organic matter on phosphorus adsorption and desorption in a black soil from Northeast China. Soil Tillage Res. (2019) 187:85-91. doi: 10.1016/j.still.2018.11.016

15. Silva FC, van Raij B. Phosphorus availability of the evaluation by several extractors in soil samples cultivated with sugarcane. J Soil Sci Brazil. (1996) 20:83-90.

16. Pavinato PS, Merlin A, Rosolem CA. Phosphorus fractions in Brazilian Cerrado soils affected by the tillage. Soil Tillage Res. (2009) 105:14955. doi: 10.1016/j.still.2009.07.001

17. Hedley MJ, Stewart JWB, Chauhan BS. Changes in inorganic and organic soil phosphorus fractions induced by cultivation practices and laboratory incubations. Soil Sci Soc Am J. (1982) 46:5:970-6. doi: 10.2136/sssaj1982.03615995004600050017x

18. Caione G, Prado R de M, Campos CNS, Rodrigues M, Pavinato PS, Agostinho FB. Phosphorus fractionation in soil cultivated with sugarcane fertilized by filter cake and phosphate sources. Commun Soil Sci Plant Anal. (2015) 46:2449-59. doi: 10.1080/00103624.2015.1081926

\section{FUNDING}

This work was supported with a scholarship to the AdA of the CNPq project (Process 151221/2014-6) and research grant from FAPESP (Process 11/12810-1).

19. Linquist BA, Ruark MD, Hill JE. Soil order and management practices control soil phosphorus fractions in managed wetland ecosystems. Nutr Cycl Agroecosyst. (2011). 90:51-62. doi: 10.1007/s10705-010-9411-3

20. Tokura AM, Furtini Neto AE, Carneiro FC, Curi N, Santos JZL, Alovisi AA. Dynamics of phosphorus forms in soils with contrasting texture and mineralogy cultivated with rice. Acta Sci Agron. (2011) 33:171-9. doi: 10.4025/actasciagron.v33i1.1435

21. Almeida AB Jr, Nascimento CWA, Sobral MF, Silva FBV, Gomes WA. Soil fertility and uptake of nutrients by sugarcane fertilized with filter cake. Rev Bras Eng Agr Ambient. (2011) 15:1004-13. doi: 10.1590/S1415-43662011001000003

22. Soltangheisi A, Santos VRD, Franco HCJ, Kolln O, Vitti AC, Dias TDS, et al. Phosphate sources and filter cake amendment affecting sugarcane yield and soil phosphorus fractions. Rev Bras Cien Solo. (2019) 43:e0180227. doi: 10.1590/18069657rbcs20180227

23. Santos HG, Jacomine PKT, Angles LHC, Oliveira VA, Lumbreras JF, Rabbit MR, et al. Brazilian System of Soil Classification. 3 ed. Rio de Janeiro: Embrapa Solos (2013).

24. Staff SS. Keys to Soil Taxonomy. Washington, DC: USDA - Natural Resources Conservation Service (2014).

25. Raij van B, Andrade JC, Cantarella H, Quaggio JA. Chemical Analysis for Fertility Assessment in Tropical Soil. Campinas: Instituto Agronômico (2001).

26. Alvarez VVH, Novais RF, Dias LE, Oliveira JA. Determinação e uso do fósforo remanescente. Boletim Informativo da SBCS, Viçosa. (2000) 25:27-32.

27. Camargo OA, Moniz AC, Jorge JA, Valadares JMAS. Methods of Chemical, Mineralogical and Physical Analysis of Soils. Campinas: IAC (2009) 77 p.

28. Bataglia OC, Furlani AMC, Teixeira JPF, Furlani PR, Gallo JR. Methods for the Chemical Plant. Campinas Agronomic Institute (1983) 48. p.

29. Raij van B, Cantarella H. Cana-de-açúcar. In: Raij van B, Cantarella H, Quaggio JA, Furlani AMC, editors. Recomendações de calagem e adubação para o estado de São Paulo. Campinas: Instituto Agronômico de Campinas (1997). p. 237-9.

30. Cross AF, Schlesinger WH. A literature review and evaluation of the Hedley fractionation: applications to the biogeochemical cycle of soil phosphorus in natural ecosystems. Geoderma. (1995) 64:197-214. doi: 10.1016/0016-7061(94)00023-4

31. Tiessen H, Moir JO. Characterization of available P by sequential extraction. In: Carter MR, editor. Soil Sampling and Methods of AnalysisCanadian Society of Soil Science. Boca Raton, FL: Lewis Publications (1993). p. 75-86.

32. Linquist BA, Singleton PW, Cassman KG. Inorganic and organic phosphorus dynamics during a build-up decline of available phosphorus in an ultisol. Soil Sci. (1997) 162:254-64.

33. Gatiboni LC, Kaminski J, Rheinheimer DS, Flores JPC. Bioavailability of phosphorous forms accumulated in soil under a direct planting system. Rev Bras Ciênc Solo. (2007) 31:691-9. doi: 10.1590/S0100-068320070004 00010

34. Condron LM, Goh KM, Newman RH. Nature and distribution of soil phosphorus as revealed by a sequential extraction method followed by 31P nuclear magnetic ressonance analysis. Eur J Soil Sci. (1985) 36:199207. doi: 10.1111/j.1365-2389.1985.tb00324.x

35. Olsen SR, Sommers LE. Phosphorus. In: Page AL, Miller RH, Keene YQR, editors. Methods of Soil Analysis, Part 2, Second ed. Chemical and Microbiological Properties. Madison: Soil Science Society of America (1982). p. 403-30. doi: 10.2134/agronmonogr9.2.2ed.c24

36. USEPA - United States Environmental Protection Agency. Methods of Chemical Analysis for Water and Wastes. Cincinnati, OH: Environmental Protection Agency (1971). p. 312. 
37. Dick WA, Tabatabai MA. Determination of orthophosphate in aqueous solutions containing labile organic and inorganic phosphorus compounds. $J$ Environ Qual. (1977) 6:82-5. doi: 10.2134/jeq1977.00472425000600010018x

38. Murphy J, Riley JP. A modified single solution method for the determination of phosphate in natural waters. Anal Chim Acta. (1962) 27:31-6. doi: 10.1016/S0003-2670(00)88444-5

39. Borges BMMN, Abdala DB, Souza MF, Viglio LM, Coelho MJA, Pavinato PS, et al. Organomineral phosphate fertilizer from sugarcane byproduct and its effects on soil phosphorus availability and sugarcane yield. Geoderma. (2019) 339:20-30. doi: 10.1016/j.geoderma.2018.12.036

40. Barbosa JC, Maldonado JRW. AgroEstat. System for Statistical Analysis of Agronomic Trials. Version 1.0. Jaboticabal: Universidade Estadual Paulista "Julio de Mesquita Filho" - Faculty of Agriculture and Veterinary Sciences (2014).

41. Oliveira LB, Tiecher T, Tables FLF, Trinity JPR, Gatiboni LC, Brunetto G, et al. Phosphorus forms in soil under natural pastures submitted to adduction phosphates. J Soil Sci. (2014) 38:867-78. doi: 10.1590/S0100-06832014000300018

42. Rossetto R, Santiago AD. Fertilization: Alternative Residues. (2015). Available online at: http://www.agencia.cnptia.embrapa.br/gestor/cana-deacucar/arvore/CONTAG01_39_711200516717.html (accessed May, 2015).

43. Hue NV. Effects of organic acids/anions on $\mathrm{P}$ sorption and phytoavailability in soils with different mineralogies. Soil Sci. (1991) 152:463-71. doi: 10.1097/00010694-199112000-00009

44. Bittencourt VC, Strini AC, Cesarim LG, Souza SR. Enriched filter cake. Idea Magazine News. (2006) 63:2-6. doi: 10.1590/S0100-06832009000200013

45. Gonçalves GK, Meurer EJ. Phosphorus fractions in soil and its relation to plant uptake of rice by flooding in the Rio Grande soils. Revista Brasileira de Ciência do Solo. (2009) 33:357-62.

46. Richards JE, Bates TE, Sheppard SC. Changes in the forms and distribution of soil phosphorus due to long-term corn production. Canad J Soil Sci. (1995) 75:311-8. doi: 10.4141/cjss95-045

47. Schimidt JP, Buol SW, Kamprath EJ. Soil phosphorus dynamics during seventeen years of continuous cultivation: fractionation analyses. Soil Sci Soc Am J. (1996) 60:1168-72. doi: 10.2136/sssaj1996.03615995006000040030x

48. Friesen DK, Rao IM, Thomas RJ, Oberson A, Sanz JI. Phosphorus acquisition and cycling in crop and pasture systems in low fertility tropical soils. Plant Soil. (1997) 196:289-94. doi: 10.1023/A:1004226708485

49. Zhang TQ, Mackenzie AF. Changes of soil phosphorus fractions under long-term corn monoculture. Soil Sci Soc Am J. (1997) 61:485-93. doi: 10.2136/sssaj1997.03615995006100020017x

50. Rheinheimer DS, Anghinoni I. Distribution of inorganic phosphorus in soil management systems. Brazil Agric Res. (2001) 36:151-60. doi: 10.1590/S0100-204X2001000100019

51. Chang SC, Jackson ML. Fractionation of soil phosphorus. Soil Sci. (1957) 84:133-44. doi: 10.1097/00010694-195708000-00005

52. Dias VMC. Solubility of natural apatitic natural phosphates in ammonium acetate in soils. Master's dissertation, Santa Maria Federal University of Rio Grande do Sul, Santa Maria (1978).

53. Carneiro LF, Resende AV, de, Furtini Neto AE, Santos JZL, Curi N, et al. Soil phosphorus fractions in response to phosphate fertilization in an Oxisol under different land uses. Revis Brasil Ciênc Solo. (2011) 35:48391. doi: 10.1590/S0100-06832011000200017

54. Sá JCM. Adubação fosfatada no sistema plantio direto. Piracicaba: Phosphorus in Brazilian agriculture (2004). p. 201-20.

55. Raij van B. Methods of Diagnosis of Soil Phosphorus in Use in Brazil. Piracicaba (2004). p. 245-59.

56. Gatiboni LC, Brunetto G, Kaminski J, Rheinheimer DS, Ceretta CA, Basso CJ. Phosphorus forms in the soil after successive additions of pig slurry on natural pasture. J Soil Sci. (2008) 32:1753-61. doi: 10.1590/S0100-06832008000400040

57. Gatiboni LC. Availability of phosphorus forms soil to plants. doctoral thesis, Santa Maria, Federal University of Santa Maria, Santa Maria (2003).

58. Soltangheisi A, Haygarth PM, Pavinato PS, Cherubin MR, Teles APB, Bordonal RdeO, et al. Long term sugarcane straw removal affects soil phosphorus dynamics. Soil Till Res. (2021) 208:104898. doi: $10.1016 /$ j.still.2020.104898
59. Conte E, Anghinoni I, Rheinheimer DS. Fractions of phosphorus accumulated in loamy Latosol by phosphate application under a no-till system. Revist Brasil Ciênc Solo. (2003) 27:896-900. doi: 10.1590/S0100-0683200300050 0014

60. Gatiboni LC, Rheinheimer DS, Florers AFC, Anghinoni I, Kaminski J, Lima MAS. Phosphorus forms and availability assessed by 31 P-NMR in successively cropped soil. Commun Soil Sci Plant Anal. (2005) 36:262540. doi: 10.1080/00103620500301917

61. Santos JZL, Furtini Neto AE, Resende AV, Curi N, Sheep LF, Costa EVG, et al. Phosphorus fractions in soil fertilized with phosphates in different modes of application and cultivated with corn. Revista Brasileira de Ciência do Solo. (2008) 32:705-14. doi: 10.1590/S0100-0683200800020 002

62. Rodrigues M, Pavinato PS, Withers PJA, Teles APB, Herrera WFB. Legacy phosphorus and no tillage agriculture in tropical oxisols of the Brazilian savanna. Sci Total Environ. (2016) 542:1050-61. doi: 10.1016/j.scitotenv.2015.08.118

63. Santos DH, Tiritan CS, Foloni JSS, Fabris LB. Produtividade de cana-deaçúcar sob adubação com torta de filtro enriquecida com fosfato solúvel. Pesquisa Agropecuária Tropical. (2010) 40:454-61.

64. Korndorfer GH, Anderson DL. Use and impact of sugar-alcohol residues vinasse and filter cake on sugarcane production in Brazil. Sugar y Azucar Englewood Cliffs. (1997) 92:26-5.

65. Li YY, Rui YANG, Ru GAO, Wei HA, Chen AL, Yong LI. Effects of longterm phosphorus fertilization and straw incorporation on phosphorus fractions in subtropical paddy soil. J Integr Agric. (2015) 14:36573. doi: 10.1016/S2095-3119(13)60684-X

66. Cherubin MR, Lisboa IP, Silva AG, Varanda LL, Bordonal RO, Carvalho JL, et al. Sugarcane straw removal: implications to soil fertility and fertilizer demand in Brazil. Bioenergy Res. (2019) 12:888-900. doi: 10.1007/s12155-019-10021-w

67. Vasconcelos R, de L, Prado, de R M, Campos CNS, Caione G, et al. Sources of phosphorus with sugar cane filter cake on the nutritional status and productivity of sugar cane (Saccharum officinarum L) cultivated in redyellow latosol. AJCS. (2014) 8:1467-74. https://search.informit.org/doi/10. 3316/informit.818258115972799

68. Kifuko MN, Othieno CO, Okalebo JR, Kimenye LN, Ndung'u KW, Kipkoech AK. Effect of combining organic residues with minjingu phosphate rock on sorption and availability of phosphorus and maize production in acid soils of Western Kenya. Exp Agric Bangor. (2007) 43:5166. doi: 10.1017/S0014479706004121

69. Rosa SD, Silva CA, Moreira Maluf HJG. Humic acid-phosphate fertilizer interaction and extractable phosphorus in soils of contrasting texture. Rev Ciênc Agron. (2018) 49:32-42. doi: 10.5935/1806-6690.20180004

70. Matias GCS. Agronomic Efficiency of Phosphate Fertilizers in Soils With Different Capacity of Phosphate Adsorption and Organic Matter Levels. Tese (Doutorado), Piracicaba (2010) 174 p.

Conflict of Interest: The authors declare that the research was conducted in the absence of any commercial or financial relationships that could be construed as a potential conflict of interest.

Publisher's Note: All claims expressed in this article are solely those of the authors and do not necessarily represent those of their affiliated organizations, or those of the publisher, the editors and the reviewers. Any product that may be evaluated in this article, or claim that may be made by its manufacturer, is not guaranteed or endorsed by the publisher.

Copyright (C) 2021 de Aquino Vidal Lacerda Soares, de Mello Prado, Caione, Rodrigues, Pavinato and Naudi Silva Campos. This is an open-access article distributed under the terms of the Creative Commons Attribution License (CC BY). The use, distribution or reproduction in other forums is permitted, provided the original author(s) and the copyright owner(s) are credited and that the original publication in this journal is cited, in accordance with accepted academic practice. No use, distribution or reproduction is permitted which does not comply with these terms. 